\title{
From controlling mobilities to control over women's bodies: gendered effects of EU border externalization in Morocco
}

\author{
Elsa Tyszler
}

\author{
Correspondence: elsa.tyszler@gmail. \\ com \\ Gender, Work and Mobility (GTM) \\ team, Centre for Sociological and \\ Political Research of Paris \\ (CRESPPA), 4 rue Victor Hugo, 93100 \\ Montreuil, France
}

\begin{abstract}
Taking the perspective of the Central and West African women blocked at the Moroccan-Spanish border, reveals how EU policies, in exporting their anti-migrant war to African countries, seem to have reinforced a continuum of male dominance: by creating, along the migratory route, a succession of spaces where African women must resist and/or succumb to multiple relations of power and domination in order to be able to cross the securitized borders, controlled by a plurality of actors but often all men. Breaking with binary and essentialist views that often present them as merely passive subjects of their migration, the women interviewed disclose hidden mechanisms and effects of the externalization of EU migration control policies on the bodies and lives of those who fight for their freedom of movement. Based on 30-months of ethnographic research in Morocco and the Spanish enclaves of Ceuta and Melilla, this article aims to show how EU border externalization provokes racialized and gendered vulnerabilization of people seeking mobility and notably reinforces gender-based violence against migrant women. There are several levels of violence against women seeking mobility at borders, we will focus on two: violence emanating from certain men who are part of the organization of the crossing, and violence exerted by the States policing the border. Both of these cases illustrate the interaction between mobility control policies and control over women's bodies as an effect of border externalization.
\end{abstract}

Keywords: Moroccan-Spanish border, Externalization, Migration policies, Race, Gender, Mobility, Violence

\section{Introduction}

In 2004, in the first Non-Governmental Organization (NGO) report on the issue of the "Sub-Saharan" migrants at the Moroccan-Spanish border, Anne-Sophie Wender of La Cimade wrote: "The three informal camps visited are made up of a population that is overwhelmingly male. Women remain an extremely small minority (...). Except for two very young babies (...) we did not meet any children in the camps" (Cimade, 2004, p.13). In June 2017, during my last field observation in the same region of Nador, near Melilla, my conclusions were different: the number of women, especially pregnant women, babies and children was visually striking, clearly offsetting the male presence, but not equal to it. But the feminization of this population is not new. Much research has been conducted on "Sub-Saharan" migration in Morocco (Alioua, 2011; Barros,

(c) The Author(s). 2019 Open Access This article is distributed under the terms of the Creative Commons Attribution 4.0 International License (http://creativecommons.org/licenses/by/4.0/), which permits unrestricted use, distribution, and reproduction in any medium, provided you give appropriate credit to the original author(s) and the source, provide a link to the Creative Commons license, and indicate if changes were made. 
Lahlou, Escoffier, Pumares, \& Ruspini, 2002; Collyer, 2007; De Haas, 2005, 2007; Khachani, 2008; Lahlou, 2005; Pian, 2009; Timera, 2009, among others). But most of the researchers have presented "Sub-Saharan" men as subjects designating social generality, women are excluded "as much from description as from theorization" (Mathieu, 1985, p.139). "Minority" and "difficult to access" are often reasons given to justify the lack of information (or interest?) regarding black women in migration in Morocco, even if they have always been there. Yet other researchers, mainly women, were already carrying out work on "Sub-Saharan women" in Morocco at about the same time (AMERM, 2008; Escoffier, 2006; Freedman, 2012; Stock, 2011, 2018). Helena Maleno, a militant known for her work on behalf of migrants' rights, as well as the reports of Médecins sans Frontières (2010, 2013) shed light on the situation of migrant women. All this academic and activist work has thus contributed to the visibility, diversification and complexity of the image of Central and West African migrant women in Morocco and shown how gender, as a structural factor of power inequality, can both constrain and allow mobility. However, much of the research dealing with migrant women in Morocco has focused on the issue of trafficking in the domestic work and prostitution sectors (ALECMA, 2016; Carrión, Kheireddine, \& Zirari, 2015; Women's Link Worldwide, 2009), and on sexual violence (Laacher, 2010; Médecins Sans Frontières, 2010, 2013), without always integrating a gender perspective, but rather reiterating a particular vision, generating the predominant figure of the migrant-woman-victim with no agency, found in the political-media discourse. Pointing to complex links between certain migrations and the practice of prostitution, researchers have already warned against a reductive vision of trafficking and smuggling. Crossed by political and ideological issues, these categorizations are not always able to account for lived experiences (Andrijasevic, 2007; Darley, 2006; Guillemaut, 2008; Jakšić, 2008; Sanchez, 2016).

Taking into account the contributions and shortcomings of previous work, an ethnographic and feminist approach seemed to be necessary to break with the binary and dominant discourses on the migratory experiences of Central and West African women at the Moroccan-Spanish border and to repoliticize and complexify the analysis of the violence they deal with. The focus on fence jumpers only allows us to apprehend the most obvious aspects of the repression of African mobility towards Europe and notably invisibilizes the experiences and resistances of women migrants, full-fledged actresses at the border, despite their numerical minority. In 2017, women represented 7,3\% of the arrivals by sea in Spain, 1634 women including 161 pregnant women (APDHA, 2018). But these figures do not tell us about the number of women that could not cross the border and who are still blocked on the Moroccan side. Taking a sociological approach, the lens of the imbrication of social relations, notably relations of gender, race and class (Combahee River Collective, 2014; Crenshaw, 1991; Kergoat, 2009), is particularly enlightening for analysing the experience of the border of black women seeking mobility. The migrant condition is also included in the mutual coproduction of relations of power and domination. Jane Freedman writes in 2004 that asylum policies have a particular effect on women, often worsening their dependency and vulnerability (Freedman, 2004). Since 2012, she has highlighted the gendered character of insecurity as it is experienced by people in exile who try to reach Europe which is increasingly reinforcing its border security (Freedman, 2016). In that sense, this article wants to show the interaction between mobility control policies and controls over racialized women's 
bodies, as an effect of border externalization. The "vulnerability of women" is not a natural characteristic of these women but is the result of the different mechanisms of oppression and dispossession in which they are caught (Butler, 2016), anchored in specific historical, social and geo-political contexts. Thus, the identification of the vulnerability allows us to denounce the political and societal situation of women, in this case the situation of black African women blocked at the borders of Europe.

Conducted in Morocco and in the Spanish enclaves of Ceuta and Melilla, the research on which this article is based, seeks to reincorporate gender ${ }^{1}$ interlinked to race ${ }^{2}$ in the analysis of the securitization of this Euro-African border and its consequences on people seeking mobility. In line with "a sociology of passage and of the border, that explores what takes place in these buffer zones" (free translation of Pian, 2009, p.205), and inspired by the work of feminist researchers on migration (Cossée, Miranda, Ouali, \& Djaouida, 2012; among many others), this article wants to study the link between border security and gender-based violence, following studies anchored in other border contexts, mainly in the Americas (Basham \& Vaughan-Williams, 2013; Cortés, 2018; Falcón, 2006, among others). Looking at the experiences of women gives us a better understanding of the interweaved systems of border control, and of the deep consequences of the EU's border externalization policies on migrants in Africa. This article aims to show how this externalization provokes racialized and gendered vulnerabilization of people seeking mobility and notably reinforces sexual violence against black migrant women.

The first part of the article gives a brief understanding of the Moroccan-Spanish border, showing the context in which the research took place and the main stakeholders involved. The second and third parts focus on two levels of violence against black African migrant women: violence emanating from certain men who are part of the organization of the crossing, analysed through the experiences of women in the camps situated in the forest on the Moroccan side; and violence exerted by States, examining the political instrumentalization of the presence of those women at the borders.

\section{Methodological note}

The fieldwork for this article was carried out in Morocco and in the Spanish enclaves of Ceuta and Melilla, in the context of a PhD in Sociology. I spent 30 months in the field between 2015 and 2017, living continuously there. This enabled me to gain privileged access for multi-situated research, and to follow, for several years, the (im)mobility of a number of candidates for Europe, within the continuity and changes of the migration policies surrounding the Moroccan-Spanish border. I lived in Rabat, a city where many candidates for Europe are based, and I made regular visits and periods of ethnographic observation, within and outside the framework of NGO missions, notably to the border cities of Tangier, Ceuta, Nador, Melilla, but also to cities connected to the border such as Oujda (city of entry to Morocco at the Algerian border), Fès or Meknès, where there are also migrants attempting to cross into the North. I used participant observation through positions I held in several NGOs in Morocco working with migrants from Central and West Africa - or rather observant participation (Malinowski, 1922) because of the full-time jobs that led me to have an active, professionalized and militant 
involvement (Makaremi, 2008). This intense participation could sometimes temporarily eclipse the researcher's lucidity and intellectual availability (Soulé, 2007, p.134). As Blondeau (2002) points out, the daily life of the participant sometimes takes over, preventing her/him from behaving like a "real researcher", having time to write down information, discuss, and step back from her/his object. Being integrated within Morocco-based NGO helped me to get access to the border area on the Moroccan side that is highly monitored by the authorities. I conducted a large number of interviews (formal and informal) with the plurality of actors/actresses gravitating (directly or indirectly) around the border: migrant women and men (about 80) mostly from Central and West Africa, but also a few from Morocco, Syria and Palestine; NGOs staff/activists based in Morocco and Ceuta and Melilla (about 60), staff of governmental and international organizations (30) including staff of European international cooperation agencies in Morocco, members of Moroccan, Spanish and European institutions, Spanish police and military personnel. The data used for this article are mainly the ones collected during fieldwork in Nador, as well as interviews and conversations in other cities alongside people who spent time at the border. If the collection of information at the border is a difficult exercise due to the increased surveillance in this area by the Moroccan and Spanish authorities, ${ }^{3}$ the distress of people seeking mobility and the violence of the context were also a central elements in the difficulty of the investigation. On many occasions, the researcher's cap had to be left aside for the activist's cap. For ethical reasons, I have decided not to disclose some of the information collected in the field in this article, even if it is relevant to the subject and would allow more detail to be given, as it would reveal some of the tools of resistance of subaltern people fighting for their freedom of movement.

\section{The Moroccan-Spanish border and its (un)desirables}

The Spanish enclaves of Ceuta and Melilla, conquered in 1492 and 1497, are remnants of the Spanish colonial empire and are historically linked to the Christian Reconquista movement of the Iberian Peninsula. After centuries of multiple colonizations and despite the independence of Morocco in 1956, the enclaves remained Spanish. While the Cherifian Kingdom officially continues to claim its sovereignty over "Sebta" and "Mliliya", it can be observed that this claim is fading as it helps Spain and the EU in the fight against illegal immigration to Europe. Today, the two enclaves materialize the only land borders between Africa and Europe. Therefore, they are an important point of focus for migration policies aiming to reduce migrations towards Europe.

\section{The military-security management of the Euro-African border since the $1990 \mathrm{~s}$}

In the European context migration issues have been entirely engulfed by the prism of security (Bigo, 2008). To ensure the securitization of European territory, the policies of the EU and its Member States have focused on preventing the arrival of irregular migrants. On the one hand, legislation on the conditions of entry and residence in European territory, as well as physical border control measures, have been strengthened. On the other hand, some border control missions have been delegated to the external agency Frontex in charge of the coordination of border surveillance and to so-called third countries (of origin of immigration or transit) to prevent the departure 
of irregularised mobilities to Europe. This is part of a more global process of outsourcing migration policies (Migreurop, 2009, 2012, 2017). Following Spain's integration into the Schengen Area in 1995, Ceuta and Melilla became an "external border" of the EU. Subject to irregular crossings, corresponding notably to the introduction of a general policy that made visas a requirement, and therefore to increasing difficulties for people from the ex-colonies wanting to reach Europe legally, this area became of great concern to Spain and its European counterparts. To remedy this, the Spanish authorities have sought to improve the impermeability of these border areas by erecting ever higher fences around the two cities, while increasing the number of control and surveillance measures. At the same time, Morocco has been encouraged to take on EU border guard tasks. It actively collaborates - between constraints and opportunities (El Qadim, 2010) - in the fight against so-called illegal immigration, in particular by mobilising its police/military personnel and building barriers to reinforce existing Spanish fences. The securing of this external border of the EU therefore requires, on both sides, the use of military and security means and devices (Tyszler, 2015).

In 2005, at least 11 Central and West African men were shot dead and hundreds wounded by soldiers when attempting to cross the Ceuta and Melilla fences (AFVIC/ Cimade, 2005; GADEM, 2007; Migreurop, 2007). More than a decade later, and despite the launch of a new Moroccan migration policy in 2013, which King Mohammed VI declared more "humane" and including notably exceptional regularization operations (Alioua, Ferrié, \& Reifeld, 2017), those named "Sub-Saharan" migrants still see their rights violated and suffer violence on the Moroccan-Spanish border area and more widely in the North of the country (AMDH Nador, 2015; Fronteras, 2017; Tyszler, 2015; GADEM, 2018; Human Rights Watch, 2014). On the other side, the legalization, through an amendment to the Spanish Aliens Act, of the "hot returns" to Morocco that have been practiced for years at the Ceuta and Melilla barriers by the Guardia Civil in collaboration with the Moroccan forces - still reckoned illegal with reference to international and European $\mathrm{law}^{4}$-, as well as the establishment of asylum offices at the enclaves' borders in 2015, have not produced any positive change in the treatment of "Sub-Saharan" people in these regions. The Spanish and Moroccan military, seem to benefit from a wide margin of manoeuvre, even a certain impunity according to some analyses (Artigas, Ortega, \& Serra, 2016; Tyszler, 2015), in their practical application of border protection policies. This is particularly the case when it comes to the control of black migration. Various studies of the security-military management of migration at this Euro-African border have been conducted: mainly from (geo)political and legal approaches (Acosta-Sanchez, 2014; Ferrer-Gallardo, 2008; Gabrielli, 2015; Moffette, 2018; Saddiki, 2010), and socio-anthropological ones alongside "Sub-Saharan" migrants (Andersson, 2014; Kobelinsky, 2017; Pian, 2008a). However, the racialized and gendered impacts of the security-military management of the border have been underexplored.

\section{Racialization processes at the border}

"Sub-Saharan" migrants are not the only foreign people trying to cross the Moroccan-Spanish border. In 2015 for instance, the Guardia civil in Melilla gave us (in the context of an inter-NGO observation mission) data showing three main groups of 
people who had arrived "irregularly" in Melilla: Syrian and Algerian nationals all arrived by the border crossing point, and "Sub-Saharans" arrived either through the barriers, by sea or hidden in cars (Tyszler, 2015, p.23). The majority of black people trying to cross the Moroccan-Spanish border come from ex-colonized countries in Central and West Africa. In Morocco and the Spanish enclaves, their migratory movements are differentiated from the mobility of other populations, notably by the degree of political repression against them - as illustrated by the many cases of violence, sometimes lethal ${ }^{5}-$ and the mediatisation around them. At the border, racialization processes shape the possibilities and modalities of crossing: during the field research, I observed that if people from Algeria or Syria can enter Melilla through the border crossing, it is impossible for a black person to do the same. Hence the establishment of the latter in camps in the forest and also the attempts to cross barriers or pass by boat, despite the risk of exposure to violent repression at the barriers and even the danger of death at the barriers or at sea. Exiled people from Syria or Algeria can (with more or less ease) use the same roads as Moroccans in the region who have a daily right of entry into the enclaves. Skin colour is thus a factor facilitating or blocking access to the border crossings of Ceuta and Melilla (AMDH Nador, 2015; Tyszler, 2015; Tyszler, 2018a), as a member of the Spanish Guardia Civil of Melilla clearly indicated in 2015 when interviewed: "There are entry routes used by Sub-Saharans: jumping the barrier, boats at sea, hiding in vehicles. Unlike Syrians who pass through the border control post, usually with falsified or stolen passports. Here, yes, there are Whites and Blacks, Sub-Saharans cannot come walking". This statement was confirmed by all the black migrants interviewed in Nador when asked if they had already tried to access the asylum office set up at the entrance to the Melilla enclave in April 2015: "Which asylum office? An asylum office in Beni-Ansar? But that's impossible, we can't get close to the border! This is for the Syrians!" replied a young Guinean national. "The asylum office is a racist system. If you are black and go near the border, you will be hit, you can't get there", explained a Nigerian man.

The differentiation also comes from descriptions in racialized and gendered terms, shaping a certain visibility, perpetuated through a range of mechanisms emanating from States, NGOs, civil society, journalists, researchers. Black Africans at the border are systematically labelled as "economic migrants" and criminalized by the authorities (national police and Guardia Civil) interviewed in Ceuta and Melilla but also in government officials' declarations picked up in the Spanish and Moroccan press. The reasons behind their migration are however very varied and can sometimes fall under asylum law. In 2015, according to the Spanish HCR, 70\% of people attempting to cross the Ceuta and Melilla barriers were potential asylum seekers. ${ }^{6}$ In June of the same year, Spain was denounced before the United Nations for violation of the right to non-discrimination. The complaint of the Comité René Cassin, an NGO of independent jurists, basically contrasts the relevant reception of Syrian asylum-seekers with the impossibility of access to the asylum offices of Ceuta and Melilla for "Sub-Saharan Africans", pointing to racial discrimination against the latter. The data I collected during my fieldwork goes in the same direction, in 2015 only Syrians (and a few Palestinians) could access the border asylum office of Melilla, not without some difficulties (see Tyszler, 2015, p.16). While not a single asylum application has been submitted by a national from Central or West Africa (Tyszler, 2015, pp.49-50). The 
representative of the Secretary General of the Council of Europe for Migration and Refugees reached the same conclusion after his visit to Melilla in September 2018. The observations and interviews conducted in the field all converge towards the same analysis: at the border, black people are particularly tracked down, prevented from crossing the border, and subject to particular violence from Moroccan and Spanish soldiers when compared with other populations attempting to enter Spanish territory such as Syrian or Algerian nationals or Moroccan emigrants. ${ }^{7}$

\section{Between forest and fences: the dehumanization of black Africans at the border}

In the Nador area, close to the Melilla enclave, migrant people and activists interviewed spoke about a "black man hunt": "In Nador you only have to be black to be arrested, Nador is a forbidden city for Sub-Saharan migrants." denounced a Moroccan human rights activist living in the border city in 2017. "They take wood and they beat you. They beat everybody, even the kids. They treat us like animals. One day they will end up killing us.", "OK, they can arrest us, we understand it is their job, but why do they torture us like that, it is not normal." Declared, in a collective interview, young Cameroonian and Guinean men repressed and forcibly displaced from the fence of Ceuta to Casablanca by Moroccan forces in 2017. The military-security stalking of black African migrants documented by numerous NGO reports (AMDH Nador, 2015; Amnesty International, 2018; Tyszler, 2015; GADEM, 2018, among others) and observed in situ during my fieldwork in the border regions of the North of Morocco, explains the reason for the encampment of a great number of them in forests, in self-built camps, since they are forced to hide while waiting to cross the border. The camps' organisation varies. However, people are often grouped by nationality and according to the mode of border crossing contemplated. No access to drinking water, no access to hygiene facilities, no supply points, deplored migrants interviewed there. Harassment takes place through repeated collective arrests, usually in the middle of the night, but also through the regular destruction of camps by fire. Theft of their property, including telephones, money in the camps, and more recently when migrants leave money transfer agencies, are also common practices. In addition, humanitarian aid at camps level is regularly prevented or destroyed by the military. Local NGOs also denounce frequent arrests of migrants on their way to hospital. As the years of repression and the increasing securitization of the border have progressed, the camps have moved further and further away from the cities and the border to escape the raids and camp destruction operations carried out by Moroccan soldiers. Some others migrants live in abandoned buildings or small houses in bad conditions they rent from locals, but arrests also take place there. The tracking policy organized at the border leads to the conclusion that there is a form of radical othering of the black people intending to migrate to Europe, and highlights the racialized character of their vulnerability and insecurity at the border. While all Black-African migrants constitute the most undesirable group that must be prevented from crossing the border, their lived experience there have also proven to be gendered. Between invisibility and selective visibility (Morokvasic, 2011), women with a variety of backgrounds and life stories, are present and play active roles at the Moroccan-Spanish border. Their narratives shed light on the interlink between control of mobility and that of the bodies of women (Tyszler, 2018b). 


\section{Hindered migration and female resistance}

The women encountered at the border during the fieldwork were mainly Senegalese, Ivorian, Guinean, Cameroonian, Congolese and Malian nationals. Between the ages of 19 and 26, the reasons for leaving their country of origin were varied and sometimes cumulative. Some of them had studied, sometimes in higher education, others had not been able to go to school at all because they come from very modest families and have therefore had to work very young. The plurality of situations and backgrounds makes it difficult to typify the profiles of these women, because they are so varied. Many of the women interviewed in the region of Nador, near the enclave of Melilla, said they had left their children in their home country, entrusted to relatives. They hoped to reach Europe in order to be able to offer them better living conditions, a good school, above all. Some were the eldest of their siblings and their mission was to help those who had remained in their home country in difficult conditions. Some women reported fleeing gender-based violence: a violent husband, a man who left them when they became pregnant out of wedlock, or a family who wanted to punish them for it. Female genital mutilation or forced marriage were also mentioned during the research. The political situation in their countries of origin, all ex-colonized countries, caused others to flee. In general, very few knew of their right to seek asylum. Finally, I met some women who were trying to cross the border who had come to Morocco in search of student and professional opportunities. Some women were also a mixture of several of the profiles described, in the sense that several reasons simultaneously motivated their departure. The routes differed between those that had come by road from their country of origin, crossing several countries (and deserts) and finally entered Morocco through Algeria or Mauritania; and those who had arrived by plane in Casablanca. Those who came by road almost all suffered sexual violence (from civilians or soldiers) on the way, especially at the borders.

Does the border-space generate a shift, a reorganisation of social relations? On the contrary, the analysis of life/survival in the forest and of the methods used to cross the border suggests that the gendered and sexual orders resist change, and that border securitization strengthens a continuum of gender-based violence against Black African women seeking mobility.

\section{Sexual division of life and work in the camps: appropriation and control of mobility- seeking bodies}

"To survive in the forest you have to be a strong man" said a lot of the men. The organisation of the forest camps - where people wait to cross by sea - is generally patriarchal. Authority is always in the hands of certain men (also from Central and West Africa): the chairmen $^{8}$ (Collyer, 2007; Pian, 2008b). They set the rules and the hierarchical order that have to be followed. The spatial organisation of the camps also suggests social control: the shelters where women sleep are often positioned close to the chairman's tent. Even though they are considered "too vulnerable" or "too weak" to bear life in the forest - according to male discourses - their presence is still desirable or even useful to the men in the camps: "At least they can go down to town to beg and bring back food because they don't get arrested. Us men get tracked down" migrant men explained me in the Nador forest in 2015. Some women recounted that they had been warned, in a more or less vague way, about what could await them in the forest: 
"I had a friend, every time, he was telling me: "I don't want you to go there". He explained me stuff, but he did not tell me everything. As I really wanted to leave, he brought me to Nador, but he was always telling me: "when you will be there, do this, do that, don't talk too much to men, don't pay too much attention to them", that's it. So I was kind of prepared when I left, I followed his advice." a young Ivorian woman explained to me.

In the camps, some women use sex work as a resource to survive in the forest and to reach their goal of going to Europe. Other women engage sexual relations in order to obtain protection from a man against other men (that may abuse them) and/or to gain access to basic resources from him to survive during their time in the forest. Others are prevented from attempting to cross the border if they do not give in to the chairman's sexual blackmail, their sea crossing depending on him. A young Senegalese woman I met in a camp in Nador in 2017 explains:

"Sometimes even if you've got money it won't help you at all. Because all the chairmen you see there they want the girls. Especially the new ones who've just arrived. Every time you give your money but you don't get to go. Why? Because the chairman's interested in you. So he's going to leave you there. Either you do what he wants, and then he takes you, or you don't want to and you stay there. That's it."

The explanation given by this woman informs us about male control over female attempts to cross the border. In the forest, being a woman means depending on the will of men who are in control of the border crossing circuit, of which the chairman is but one link in the chain. Some women will therefore see their waiting period in the forest extended and therefore risk further sexual blackmail, sexual violence or rape, from soldiers or Moroccan civilians occasionally entering the camp, or from migrant men: "When I was in the forest, I didn't sleep at night, I was too scared that a man would come into my bunker [name given to the shelters]. So I used to stay up all night, I found it safer to sleep during the day. I did that for three months," explained me the young woman.

In this context, some women will give up on the idea of crossing, while others will persevere. The plurality of situations makes it difficult to talk in general terms. However, these power relations can be understood within the sexual-economic exchange system in which sexuality is seen as a service provided by women in exchange for compensation by men. Through this model, Tabet (2004) deconstructs the notion of the prostitute as an ideological figure, by showing that almost any woman can be placed within this system - that she calls "continuum" - in which sexuality is seen as a currency between two partners. In the same way, Pheterson (2001) questions the stereotype of the prostitute, by analysing the "whore stigma" as something that is not limited to a definition of prostitution as a transaction in which sexual services are exchanged for money, but also as a tool for the social and political control of women in general. However, Tabet and Pheterson also show that sex work can constitute a way for women to assert themselves as subjects and be in possession of their own labour. Pian (2010) also shows this with the example of Senegalese women living in Morocco, who without being part of human trafficking networks, offer sexual services and exchanges as a means to ensure their economic survival in the context of hindered migration. 
"Women are actively producing and reproducing their gender roles and identities in order to increase access to social and physical mobility, often by incorporating their children into the process" analyses Stock (2011, p.17) based on her field research on African migrant mothers in Rabat.

The social relations between migrant men and women in the forest are plural and complex. Situations vary from one camp to the next and one group to the next. Some stories speak of fraternal relationships of solidarity between women and men. Some men do not fit into the frames of domination described above, and some chairmen are appreciated, considered trustworthy and supportive. It is thus necessary to make nuanced analyses. However, it appears that the deadlock situation and security-military management of the border obviously reinforces a vulnerable femininity of women and a virile masculinity of men. Faced with violent repression from Moroccan and Spanish soldiers, particularly around the fences, migrant men seem to take refuge in a self-production of oneself as a "brave soldier" risking his life on the frontline (Tyszler, 2018a). The border context creates the control over women's bodies within the crossing organization.

\section{(Un)desirable women: gender logics at the border}

As previously mentioned, to cross through to Spain, three main methods are used by people who come from Central and West Africa: crossing the Melilla and Ceuta fences, entering through a border checkpoint while hidden in a vehicle, and crossing by sea. ${ }^{9}$ "Crossing the barriers is for men" according to most migrating people I met. At the border, women generally have to cross through the sea, ${ }^{10}$ on zodiac boats that charge for the crossing. To increase chances of a successful sea crossing, pregnancy is a common strategy (Kastner, 2010; Stock, 2011). This is the result of observations made by migrant people who analysed that Spanish rescue authorities were more likely to intervene if they knew pregnant women (or women with children) were on board, a shared view amongst all the people I interviewed. "When we're in the water and we call Salvamento [sea rescue organisation], they always ask if there are pregnant women or children. If there aren't any they might delay their intervention. When Salvamento comes, people are then taken to the Spanish side", explains a young Senegalese woman who twice experienced unsuccessful crossings. Therefore, some women try to get pregnant or are "encouraged" (in a more or less coerced way) to do so in order to increase their chances of accessing a Zodiac boat. Their presence is therefore profitable to men. According to Sanchez (2016, p.1) and her findings on the Mexico-US border, "While frequently overlooked within the mainstream rhetoric of smuggling dominated by male-centred narratives of exploitation, victimisation and violence, women play fundamental roles in the facilitation of irregular migration." She argues that "the facilitation of irregular migration constitutes for its participants a valid, legitimate form of labour. Smuggling actors are neither predators nor victimisers, but rather ordinary people experiencing the tensions abundant in the precarity of contemporary, neoliberal life." At the Moroccan-Spanish border, if women can negotiate their passage strategically re-appropriating their pregnant body, it seems that the non-pregnant women's bodies are more controlled. The day of possible crossing, female menstruation is forbidden: "That's catastrophic, that's why if you're on your period no one must know. They say 
that when a girl is on her period she can't go out on the sea otherwise the sharks will come", "If the chairman finds out he won't put you in the convoy" explained multiple women I met at the border. This prohibition forces them to adopt strategies to avoid menstruation: "We swallowed a whole bunch of stuff over there! All the girls did really. We used to take two, four [contraceptive] tablets a day. Some girls even swallowed whole packets, it's dangerous! But it's to travel! To travel people are capable of anything!"

Those narratives help us understand that women face even more constraints than men, even within their own bodies, which they have to control at all costs or lend to male strategizing in order to hope to cross. Also, the women that have given birth at the border in Morocco, will often have to wait for at least a year or several years before getting access to crossing attempts: "New born babies are not accepted on convoys because they are too weak and they can make a lot of noise, and that is not good when you have to be discrete to leave the coast" explained an Ivorian woman in Nador. It seems clear that women might be more prone to 'getting stuck' at the border, even if children and gender are often used by women deliberately to enhance their opportunities for mobility (Stock, 2011). We see how gender relations influenced the possibilities of mobility in this blockage/passage context also traversed by race and economic relations. The more money you have, the less you will be stuck at the border, but being a woman at the border can nullify that logic because of the sexualisation of the female body. Can this kind of asymmetrical negotiations between migrant men and women be called "human trafficking"? It must be noticed that Moroccan and Spanish authorities make use of this rhetoric in order to rebrand their repressive policies at the border. However sexual violence against black migrant women, but also sometimes against black men or minors at the border, is sometimes committed by Moroccan forces, as evidenced by interviews with migrants and activists and certain unpublished reports from NGOs that have preferred to remain anonymous about these allegations. On the Spanish side, sexual abuse has also been reported on exiled people, as illustrated by the case of a worker at the temporary residence centre for immigrants (CETI) in Melilla accused of sexual abuse and harassment by Syrian asylum seekers in $2015 .{ }^{11}$ Finally, in the same year, members of the Melilla police were accused of sexual assaults on unaccompanied Moroccan minors. ${ }^{12}$

\section{Humanitarian policies for the rescue of migrant women? Gendered rationales in migratory governance}

It is interesting to understand what is made visible in the staging of the black female migrant figure as (necessarily) a victim of human trafficking. Taking into account the work of academics who have already shown how the visibility of women "remains selective, incomplete and biased" (Morokvasic, 2011), we can see how the Moroccan and Spanish governments manipulate the issue of human trafficking in order to legitimise their violent border policies, by using a rationale already used in other securitization contexts. This categorisation amalgamates a plurality of scenarios and complex personal stories and depoliticises the violence suffered by these women, it also denies them their agency.

\section{On both sides of the border: instrumentalizing human trafficking}

In February 2015, a large-scale security operation was organised in the Nador forest. It is interesting to specify that it occurred just a few hours after the official closing speech 
of the first exceptional regularisation operation in Morocco, within the framework of the new migration policy. On February 10th, more than 1200 people were arrested in the forest of Gourougou, an important site for candidates to Europe, and taken to improvised detention sites in various Southern towns, outside all legal frameworks (CCSM and Tyszler, 2015; Üstübici, 2015). One day later, a statement by the Ministry of the Interior explained that it had proceeded to: "the release of a number of migrants, among which women and children, who had been forced to live in the forest by people smuggling and human trafficking networks". It warned: "similar operations [would be] systematically carried out in order to evacuate all the areas squatted by migrants planning on organising irregular emigration attempts" (Ministry of the Interior press release of 11 February 2015).

Without denying the existence of human trafficking in Morocco and at the Northern borders, it is important to notice the semantic shift that has taken place during the past few years, from "the fight against irregular migration" to "the fight against human trafficking". Mai (2014) suggests that we must remain critical towards operations that fall under what he calls "sexual humanitarianism", which in actual fact operate towards restricting the mobility of migrant groups that are strategically essentialised and "othered" as "pure" victims of oppression and sexual exploitation. Looking at the February 2015 raid, very few women and children were counted among the 1200 people arrested. More importantly, no actions were taken by the authorities to either identify or protect potential victims of human trafficking.

On the Spanish side, in Ceuta and Melilla, despite the existence of a protocol to "detect human trafficking victims", the protection of migrant women identified as potential victims of human trafficking seems to exist only as a discourse as no specific measures are taken.

"The police don't want to transfer all the women victim of human trafficking to the peninsula because they fear it will become a pull factor" explains the head of the Melilla temporary migrant centre in 2015. Yet, according to him "all the Sub-Saharan women are human trafficking victims, 99\%", and this is repeatedly stated in the press and reckoned as "modern slavery". ${ }^{13}$ This may be part of the border spectacle, "these various moments and forms of production and of the power-knowledge networks that constitute the border regime and give rise to their public image." (De Genova, Mezzadra, \& Pickles, 2015, p. 68). Here, the authorities are producing two racist and sexist stereotypical figures: the "Sub-Saharan woman-victim of trafficking" versus the "Sub-Saharan male-trafficker".

On both sides of the border, the concept of human trafficking when linked to that of irregular migration, serves to criminalise migratory movements of the black African and to justify a certain management of the border, even beyond legal boundaries. No coherence can be found between discourse, law and practice: the said "victims of human trafficking" at this border receive no real protection in Morocco nor in the enclaves, nor are they automatically transferred to the Spanish peninsula (Tyszler, 2015). Recently, the Council of Europe's Group of Experts against Trafficking in Human Beings expressly urged Spanish authorities to improve identification protocols and assistance to potential victims of trafficking, notably minors, in Ceuta and Melilla (GRETA, 2018). The authorities pretend their policies would be "pro-women's rights", they absolve themselves of their responsibility in the violence perpetrated against Black people 
in exile at the border, and notably against women stuck in these spaces surrounded by impunity.

\section{Dealing with their vulnerabilization: women as daily fighters at the borders}

At the borders, "women's vulnerability" may be considered as a self-fulfilling prophecy (Merton, 1948), constructed in order to produce compassion, for political purposes. This concept, used as such, sees black female migrants only as passive victims of their own migration, naturally weak and already dominated by their black male counterparts, thus in need of liberation. According to Giorgia Serughetti who worked on the case of Nigerian women asylum-seekers in Italy, the separation of migrants into categories such as trafficked/smuggled or forced/voluntary, "derives from the application of rigid bureaucratic labels to increasingly fluid migratory identities, and from gendered and neo-colonial stereotypes that inform views of agency and vulnerability" (Serughetti, 2018, p.16). Not only does this paternalistic model invisibilize the sexist and racist effects of State policies, but it also conceals the agency these women have (Butler, 2016). "I left on my own with my own money, I am a fighter, no one helped me. Everyone counts on me. We cope, we don't have a choice" explained Marlyse, a woman from Cameroon met on the border with her daughter in 2017. It is important to see the multiple forms of agency put in place when faced with increased border controls. The fieldwork alongside women taught me that they react in multiple ways in response to race and gender assignments that constrain their mobility: by resilience, such as those who accept sexual relations with chairmen to access a zodiac crossing - and here "to give in is not to consent" as Mathieu (1985) says referring to the material and psychological determinants of women's dominated consciousness. By the reappropriation of these assignments, such as the women who plan to arrive in the forest while already pregnant. Or by their circumvention, as some rare women "barrier shockers" have done, having tried a crossing mode considered masculine; or by some women that try to transcend the racial line of the border: "when you are light skinned, you can try to walk to the border disguised as a Moroccan with the veil, and you follow the crowd by praying that you will not be controlled" explained me a Guinean woman in Nador in 2017. Women perceive their female bodies as a handicap that will make them suffer doubly throughout their migration route, but at the same time it can constitute the tools of their survival and resistance strategy.

The women I met on the border condemn the specific violence that affects them and the additional efforts they have to make to cope with it. They state that they have to fight "twice as hard", as black and women, when faced with the obstacles to their mobility. Some of them also state having to fight "twice as hard", also in the sense that they have to fight for themselves but also for their child born on the way as a result of a partner-father "gone to find Europe on his own" or after a rape-related pregnancy.

"Women suffer more than men. He is on his own, so it is easier for him to cross. When I hear you have to climb over the barriers, but how do you do that when you have a child? It's more difficult for women, especially when you have a child. On the road you are always vulnerable (...) Men don't get raped like that, women always, it's unavoidable. (...) Women always suffer, always. We're a lot braver, we fight for ourselves and for our child. Men only fight for themselves. You have to fight for two 
people. He should be fighting for three people but he's decided to fight only for himself. To this date I still don't know where he is. So I'm here, with my child, I fight for her, I fight for myself, It's not easy but I have no choice. Many women are in this situation." Excerpt of an interview with a Congolese woman, Rabat, 2017.

As Butler (2016) shows, any individual who makes a claim to resist different forms of government takes the risk of being exposed to suffering by engaging their body in the public space. Thus, black women at the borders can be considered as integral parts of the resistance taking place against racist and violent migration policies meant to protect Europe and anchored in the coloniality of power (Quijano, 2000), but also against the violence coming from the Moroccan side where anti-black racism is rooted in pre-colonial history (El Hamel, 2012). Moreover, they fight the sexist and sexual violence reinforced by the securitization of the border but effective from their countries of origin and at every stage of their journey. Through their very presence at the border, they mark their will to wrest their freedom of movement.

\section{Conclusion}

The intertwined effects of gender, race and border securitization policies are varied and complex. However, an enduring tendency can be identified on every level - States (discourses, policies), local (law enforcement agencies, civilians), micro-local (within the migrant population itself) - to take advantage of certain women's presence and to control their mobility and sexuality. It seems clear that the externalisation of EU borders in Africa worsens the violence perpetrated against women seeking mobility throughout the migration process because it creates a continuum of spaces where black women have to resist and/or give in to relations of power of gender, race and class in order to cross securitized borders. The closing of borders, increasingly further away from actual European borders, make the migratory routes long and difficult for African women who could not apply for or obtain a visa. In their search for mobility, these women are therefore often forced to find a "protector" from the start or during their journey (Freedman, 2012; Freedman \& Jamal, 2008). This leads to an immediate loss of autonomy and independence for these women, who have to include a man in their migratory project in order to hope for some degree of security. Through the fieldwork, it appeared that the number of women who have been raped by soldiers or civilians, on their journey and during their time stuck on the border, is so significant that one cannot consider sexual violence as isolated or occasional but rather as systemic in the context of these hindered mobilities. "It is impossible to meet a Sub-Saharan woman who has travelled to Morocco and who hasn't suffered from sexual violence on the way or on the border. The rare women who have not been harmed are isolated cases" explains the medical agent of an ONG working with migrant women in Morocco. "That's the price women have to pay for traveling" normalize many of the migrant women I met to survive. Behind the dramatic confrontations representative of the "war on migrants" that take place on the barriers of Ceuta and Melilla, between Spanish/Moroccan soldiers and black migrant men, a "low intensity" ${ }^{14}$ war, far less visible, is fought by a larger spectrum of actors, against black women in search of mobility. Simultaneously to the racist social order imposed on black people through a violent execution of migratory governance at the border, a gendered and sexual order seems to be perpetually 
reinstated there, reinforcing the masculine domination continuum. Moreover, it must be noticed that, in the space of a few years, the issue of controlling migratory movements and securing EU borders has appeared to become an important military-industrial complex (PorCausa, 2017; Akkerman, 2018), which, like other military-industrial complexes, tends to reinforce violence against women (Michel, 1985), within a globalized capitalist system. According to Elsa Dorlin, "for some, the issue of defence does not cease when the moment of defined political mobilisation comes to an end, but is a continued lived experienced, a phenomenology of violence" (free translation of Dorlin, 2017, p.17). Far from the figure of the passive victim, black women on the borders resist and use their ingenuity on a daily basis in order to face externalised EU border control policies and gender, race and class assignations. They fight back and persevere in their quest for mobility, in the hope that they too 1 day can say: "boza"15!

\section{Endnotes}

${ }^{1}$ Gender is the social, historical and hierarchical construct created from the sexes of women and men. This concept is at the center of a double perspective of demand and social transformation. Scott, J.W. (2012). De l'utilité du genre, Paris, Fayard.

${ }^{2} \mathrm{We}$ understand the term "race" as a social, historical and political relations of appropriation (Guillaumin, 1972). It refers to "a category used for critical analysis to designate and analyse racialisation processes, that is to say differentiation systems that are stigmatising or discriminating” Dorlin, E. (Ed.). (2009). Sexe, race, classe. Pour une épistémologie de la domination, Paris, Presses universitaires de France (p.15).

${ }^{3} \mathrm{~A}$ certain number of people having tried to work on migratory topics have been evicted from Morocco or prevented from entering. See for instance members of Amnesty International's case in 2015: https://www.lemonde.fr/afrique/article/2015/06/ 12/le-maroc-expulse-des-experts-d-amnesty-international_4653314_3212.html

${ }^{4}$ The direct repression on the borders of Ceuta and Melilla, by the Guardia civil, in collaboration with their Moroccan counterparts, violates the European Convention on Human Rights and the Geneva Convention in so far as they constitute collective deportations. Spain has been condemned for this practice by the European Court of Human Rights (see: CEDH, 3 octobre 2017, N.D. et N.T. c. Espagne, req. n 8675/15 et 8697/15) as well as the UN.

${ }^{5}$ While not all deaths at the Moroccan -Spanish border have been documented, examples include the 11 gunshot deaths and hundreds of wounded in 2005 at the borders of Ceuta and Melilla; the death of a Cameroonian national as a result of violence by Moroccan soldiers in 2013, which gave rise to "Campaign No. 9" against border violence; the 15 deaths (at least) in Tarajal (Ceuta) in 2014 due to the use of riot control equipment by the Guardia civil.

${ }^{6}$ Ramajo, J. (2015). España, denunciada ante la ONU por discriminación racial en la frontera con Marruecos., El Diario. https://www.eldiario.es/andalucia/discrminacionracial_0_402110096.html

${ }^{7}$ Despite the greater proportion of violence on migrants from Central and West Africa, some cases of serious violence have been reported on other nationals: such as the case of the young Moroccan Hayat, shot dead by the Moroccan Royal Navy in September 2018: https://ledesk.ma/2018/09/26/ 
go-fast-mitraille-par-la-marine-royale-le-deces-dune-jeune-femme-de-22-ans-atteste/. Police violence against isolated Moroccan minors is also regularly reported in Melilla, see the report of the collective Harraga published in 2016 (online).

${ }^{8}$ In this context, the "chairman" or "thiaman" appoints a camp leader in the surrounding forests of the enclaves of Ceuta and Melilla, where candidates for border crossing are gathered. They are the ones who draw up the lists of people who board each "convoy" that will go to sea. Chairmen are often "former migrants" who tried the passage themselves. They often end up doing it again, when the business goes bad or when they are tired and want to go to Europe.

${ }^{9}$ The price of crossing by zodiac varies depending on the terms and the destination (enclaves or peninsula). The price of crossing hidden in a vehicle to enter an enclave can be double/triple that of a zodiac crossing, as it is less risky and takes less time. Attempting to cross through the barriers is "free" in financial terms.

${ }^{10}$ Women who have higher economic capital can attempt to cross by hiding in vehicles.

${ }^{11}$ See: https://www.elmundo.es/sociedad/2016/02/24/56cde18122601daf4d8b469a.html

${ }^{12}$ See: https://elpais.com/politica/2015/10/20/actualidad/1445333188_241964.html

${ }^{13}$ See for instance the article of May 2018 untitled "More than $90 \%$ of migrant women arriving in Ceuta come under a trafficking network": https://www.ceutaactuali dad.com/articulo/inmigracion/mas-90-mujeres-migrantes-llegan-ceuta-vienen-red-trata/ 20180527103618066208.html

${ }^{14}$ The concept of low intensity war associated to violence against women have been used by feminists as Rita L. Segato, notably in South America notably to analyse feminicides. The french sociologist Jules Falquet also uses it in her work on violence against women in times of war and peace, in the context of neoliberal globalisation.

15"Boza" is the expression used by central and West African migrants attempting to reach Europe when they manage to cross the border. The term is thought to come from Wolof or Bambara according to different explanations.

\section{Abbreviations}

NGO: Non-governmental organization

\section{Acknowledgements}

I thank the participants of this research and particularly the people in migration who shared their stories and points of view with me. I am grateful for very useful comments on earlier versions of this article provided by the guest editors of this Special Issue and by the reviewers of the journal. I also thank Jane Freedman for her proofreading; Nora El Qadim and Inka Stock for their goodwill that led me to propose this article.

Funding

Not applicable.

Availability of data and materials

Data sharing is not applicable to this article as no quantitative datasets were generated during the study. The qualitative datasets are not publicly available for the respect and protection of the research subjects.

Authors' contributions

The author was the sole person involved in researching and writing. The author read and approved the final manuscript.

Ethics approval and consent to participate

All participants were informed about the nature of the research. I uphold high ethical standards while conducting it and took elaborate measures to ensure anonymity and confidentiality of participants' information. 


\section{Competing interests}

The author declares that she has no competing interests.

\section{Publisher's Note}

Springer Nature remains neutral with regard to jurisdictional claims in published maps and institutional affiliations.

Received: 28 August 2018 Accepted: 20 February 2019

Published online: 18 June 2019

\section{References}

Acosta-Sanchez, M. (2014). Melilla: Fronteras terrestres, vallas y tierra de nadie [Melilla: Land borders, fences and no man's land]. Revista Electrónica de Estudios Internacionales. https://doi.org/10.17103/reei.28.07.

AFVIC/Cimade. (2005). Refoulements et expulsions massives de migrants et demandeurs d'asile [Push back and mass expulsions of migrants and asylum seekers]. Retrieved from http://atmf.org/Recit-d-unemission-de-I-AFVIC-et.

Akkerman, M. (2018). Expanding the fortress. The policies, the profiteers and the people shaped by EU's border externalisation programme. Retrieved from https://www.tni.org/en/node/24130?content_language=en.

ALECMA (2016). Rapport d'enquête sur le travail des femmes domestiques subsahariennes au Maroc [Survey report on the work of sub-Saharan women domestic workers in Morocco]. Rabat: https://docplayer.fr/68120640-Alecma-association-lumiere-sur-Iemigration-au-maroc-rapport-d-enquete-sur-letravail-des-femmes-domestiques-subsahariennes-au-maroc.html.

Alioua, M. (2011). L'étape marocaine des transmigrants subsahariens en route vers l'Europe: l'épreuve de la construction des réseaux et de leurs territoires [The Moroccan stage of the sub-Saharan transmigrants on the way of Europe: The ordeal of building networks and their territories]. Thèse de sociologie. Université Toulouse II Le Mirail. https://tel.archives-ouvertes.fr/ tel-00639285.

Alioua, M., Ferrié, J.-N., \& Reifeld, H. (Eds.) (2017). La nouvelle politique migratoire marocaine [The new Moroccan migration policy]. Retrieved from http://www.kas.de/wf/doc/kas_51242-1522-1-30.pdf?180124171336

AMDH Nador. (2015). Rapport Sur la situation des subsahariens à Nador [Report on the situation of sub-Saharan Africans in Nador]. Retrieved from http://www.pnpm.ma/wp-content/uploads/2017/04/rapport-migration-2015-AMDH-Nador-1.pdf.

AMERM (2008). Limmigration subsaharienne au Maroc: Analyse socio-économique [Sub-Saharan immigration in Morocco: socioeconomic analysis]. Retrieved from http://amerm.ma/wp-content/uploads/2014/02/Del'afrique-subsaharienne-au-MarocLes-réalites-de-la-migration-irregulière.pdf.

Amnesty International (2018). Maroc. Des milliers de réfugiés et de migrants subsahariens sont visés par Une répression illégale continue [Morocco: Relentless crackdown on thousands of sub-Saharan migrants and refugees is unlawful]. Retrieved from https://www.amnesty.org/fr/latest/news/2018/09/morocco-relentless-crackdown-on-thousands-of-sub-saharan-migrantsand-refugees-is-unlawful/.

Andersson, R. (2014). Illegality, Inc.: Clandestine migration and the business of bordering Europe. Oakland: University of California Press.

Andrijasevic, R. (2007). Beautiful dead bodies: Gender, migration and representation in anti-trafficking campaigns. Feminist Review, 86(1), 24-44. https://doi.org/10.1057/palgrave.fr.9400355.

APDHA. (2018). Derechos humanos en la Frontera Sur [Human rights on the southern border]. Retrieved from https://www. apdha.org/media/informe-frontera-sur-2018-web.pdf.

Artigas, X., Ortega, X., \& Serra, M. (2016). Tarajal: Desmontando la impunidad en la Frontera Sur [Tarajal: Dismantling impunity on the southern border]. [Video file]. Retrieved from https://www.documentamadrid.com/documentamadrid16/es/ficha/ pelicula/tarajal-desmontando-la-impunidad-enla-frontera-sur/.

Barros, L., Lahlou, M., Escoffier, C., Pumares, P., \& Ruspini, P. (2002). L'immigration irrégulière subsaharienne à travers et vers le Maroc [Sub-Saharan irregular immigration through and to Morocco]. Cahiers des migrations Internationales, 54. Genève: Bureau International du Travail.

Basham, V. M., \& Vaughan-Williams, N. (2013). Gender, race and border security practices: A profane Reading of 'muscular liberalism'. The British Journal of Politics and International Relations, 15(4), 509-527. https://doi.org/10.1111/j.1467-856X.2012.00517x.

Bigo, D. (2008). Le "phagocytage" des questions de migration et de libre circulation en Europe par les enjeux de sécurité? [the "engulfment" of migration and free movement issues in Europe by security issues?]. Migrations Société, 116(2), 73-84.

Blondeau, C. (2002). La boucherie: Un lieu d'innocence? [The butchery: a place of innocence?]. Ethnographiques.org, 2.

Butler, J. (2016). Rethinking vulnerability and resistance. In J. Butler, Z. Gambetti, \& L. Sabsay (Eds.), Vulnerability in resistance, (pp. 12-27). Durham: Duke University Press.

Carrión, A., Kheireddine, A., \& Zirari, M. (2015). Traite des femmes et des enfants au Maroc [Trafficking in women and children in Morocco]. Retrieved from http://maghreb.unwomen.org/fr/ressources-medias/publications/2015/03/la-traite-des-femmeset-des-enfants-au-maroc

CCSM \& GADEM (2015). Note d'information Conjointe CCSM - GADEM Sur les déplacements et les détentions arbitraires de migrants au Maroc à la suite des rafles du 10 février 2015 [Information note on the arbitrary displacement and detention of migrants in Morocco following the 10th of February raids. Retrieved from http://loujna-tounkaranke.org/wp-content/ uploads/2018/03/20150219___NoteCCSM_GADEM_detention_migrants-VF-2.pdf.

Cimade. (2004). La situation alarmante des migrants subsahariens en transit au Maroc et les conséquences des politiques européennes [The alarming situation of sub-Saharan migrants in transit in Morocco and the consequences of European policies]. Retrieved from https://www.lacimade.org/wp-content/uploads/2009/03/rapportMarocCimade.pdf.

Collyer, M. (2007). In-between places: Trans-Saharan transit migrants in Morocco and the fragmented journey to Europe. Antipode, 39(4), 668-690. https://doi.org/10.1111/j.1467-8330.2007.00546.x.

Cortés, A. (2018). Violencia de género y Frontera: Migrantes centroamericanas en México hacia los EEUU [Gender-based violence and border: Central American migrants in Mexico heading to the US]. European Review of Latin American and Caribbean Studies. https://doi.org/10.18352/erlacs.10321.

Cossée, C., Miranda, A., Ouali, N., \& Djaouida, S. (2012). Le genre au coeur des migrations [Gender at the heart of migration]. Paris: Editions Petra. 
Crenshaw, K. (1991). Mapping the margins: Intersectionality, identity politics, and violence against women of color. Stanford Law Review, 43(6), 1241-1299. https://doi.org/10.2307/1229039.

Darley, M. (2006). Le statut de la victime dans la lutte contre la traite des femmes [the status of the victim in combating trafficking in women]. Critique Internationale, 30(1), 103-122. https://doi.org/10.3917/crii.030.0103.

De Genova, N., Mezzadra, S., \& Pickles, J. (Eds.) (2015). New keywords: Migration and borders. Cultural Studies, 29(1), 55-87.

De Haas, H. (2005). Morocco: From emigration country to Africa's migration passage to Europe. Retrieved from https://www. migrationpolicy.org/article/morocco-emigration-country-africas-migration-passage-europe.

De Haas, H. (2007). The myth of invasion-irregular migration from West Africa to the Maghreb and the European union. Oxford: International Migration Institute, University of Oxford.

Dorlin, E. (2017). Se défendre. Une philosophie de la violence [Self defence. A philosophy of violence]. Paris: La Découverte.

El Hamel, C. (2012). Black Morocco. A history of slavery, race, and Islam. Cambridge University Press. https://doi.org/10.1017/ CBO9781139198783.

El Qadim, N. (2010). La politique migratoire européenne vue du Maroc: contraintes et opportunités [Confronting European Migration Policy: Dealing with Constraints and Finding Opportunities? The Case of Morocco]. Politique Européenne, 31, 91-118. https://doi.org/10.3917/poeu.031.0091.

Escoffier, C. (2006). Communautés d'itinérance et savoir-circuler des transmigrant-e-s au Maghreb. [ltinerant communities and the ability to move of transmigrants in Maghreb]. Retrieved from https:/tel.archives-ouvertes.fr/tel-00085929.

Falcón, S. (2006). "National security" and the violation of women: Militarized border rape at the US-México border. In INCITE, Color of violence: The incite! Anthology, (pp. 119-129). Cambridge: South End Press.

Ferrer-Gallardo, X. (2008). The Spanish-Moroccan border complex: Processes of geopolitical, functional and symbolic rebordering. Political Geography, 27(3), 301-321.

Freedman, J. (2004). Introduire le genre dans le débat Sur l'asile politique. L'insécurité croissante pour les femmes réfugiées en Europe [gendering the political asylum debate. Growing insecurity for refugee women in Europe]. Les cahiers du CEDREF. Centre d'enseignement, d'études et de recherches pour les études féministes, 12, 61-80.

Freedman, J. (2012). Analysing the gendered insecurities of migration: A case study of female sub-Saharan african migrants in Morocco. International Feminist Journal of Politics, 14(1), 36-55. https://doi.org/10.1080/14616742.2011.631281.

Freedman, J. (2016). Engendering security at the Borders of Europe: Women migrants and the Mediterranean 'crisis. Journal of Refugee Studies, 29(4). https://doi.org/10.1093/jrs/few01.

Freedman, J. \& Jamal B. (2008). Violence à l'égard des femmes migrantes et réfugiées dans la région Euromed Violence against migrant and refugee women in the Euromed region]. Retrieved from https:/docs.euromedwomen.foundation/files/ermwfdocuments/5118_1.21.violenceal'egarddesfemmesmigrantes.pdf.

Fronteras C. (2017). Tras la Frontera [Across the border]. Retrieved from https://caminandofronteras.files.wordpress.com/2017/ 05/ccf-itlf-arte-final-web.pdf.

Gabrielli, L. (2015). Réccurrence de la crise frontalière: l'exception permanente en Espagne [Recurring border crises: Permanent exception in Spain]. Cultures \& Conflits, (99-100), 75-98. https://doi.org/10.4000/conflits.19091.

GADEM (2007). La chasse aux migrants aux frontières Sud de l'Europe [The hunt for migrants at Europe's southern borders]. Retrieved from http://www.gadem-asso.org/la-chasse-aux-migrants-aux-frontieres-sud-deleurope/

GADEM (2018). Coûts et blessures [Costs and injuries]. Retrieved from https:/www.lacimade.org/wp-content/uploads/2018/10/ 20180927_GADEM_Couts_et_blessures.pdf.

GRETA (2018). Report concerning the implementation of the council of Europe convention on action against trafficking in human beings by Spain. Retrieved from https://rm.coe.int/greta-2018-7-frg-esp-en/16808b51e0.

Guillaumin, C. (1972). Lidéologie raciste [The racist ideology]. Paris: Gallimard.

Guillemaut, F. (2008). Mobilité internationale des femmes, échange économico-sexuel et politiques migratoires: la question du "trafic" [International mobility of women, economic and sexual exchange and migration policies: The issue of "trafficking"]. Les cahiers du CEDREF, 16, 147-168.

Human Rights Watch. (2014). Abused and expelled. III-treatment of sub-Saharan African migrants in Morocco. Retrieved from https://www.hrw.org/report/2014/02/10/abused-and-expelled/ill-treatment-sub-saharan-african-migrants-morocco.

Jakšić, M. (2008). Figures de la victime de la traite des êtres humains: de la victime idéale à la victime coupable [Figures of the victim of human trafficking: From the ideal victim to the guilty victim]. Cahiers Internationaux de Sociologie, 124(1), 127-146. https://doi.org/10.3917/cis.124.0127.

Kastner, K. (2010). Moving relationships: Family ties of Nigerian migrants on their way to Europe. African and Black Diaspora: An International Journal, 3(1), 317-351.

Kergoat, D. (2009). Dynamique et consubstantialité des rapports sociaux [dynamics and consubstantiality of social relations]. In E. Dorlin (Ed.), Sexe, race, classe. Pour Une épistémologie de la domination [Sex, race, class. For an epistemology of domination]. Paris: Presses Universitaires de France.

Khachani, M. (2008). La migration clandestine au Maroc [Clandestine migration in Morocco] (CARIM-AS 2008/50). Retrieved from http://cadmus.eui.eu/bitstream/handle/1814/10094/CARIM_AS\%26N_2008_50.pdf?sequence=1.

Kobelinsky, C. (2017). Exister au risque de disparaitre. Récits Sur la mort pendant la traversée vers l'Europe [existing at risk of disappearing. Narratives on death during border crossing]. Revue Européenne des Migrations Internationales, 33(2), 115-131.

Laacher, S. (2010). De la violence à la persécution, femmes Sur la route de l'exil [From violence to persecution, women on the road to exile]. Paris: La Dispute.

Lahlou, M. (2005). Les migrations irrégulières entre le Maghreb et l'Union européenne: Évolutions récentes. Ilrregular migration between the Maghreb and the European Union: Recent developments] (Rapport de recherche 2005/03). Retrieved from http://cadmus.eui.eu/bitstream/handle/1814/6278/CARIMRR_2005_03.pdf?sequence=1

Mai, N. (2014). Between embodied cosmopolitism and sexual humanitarianism: The fractal mobilities and subjectivities of migrants working in the sex industry. In V. Baby-Collins, \& L. Anteby (Eds.), Borders, mobilities and migrations, perspectives from the Mediterranean in the twenty-first century, (pp. 175-192). Brussels: Peter Lang.

Makaremi, C. (2008). Participer en observant. Étudier et assister les étrangers aux frontières. [Participate by observing. Study and assist foreigners at borders]. In D. Fassin, \& B. Alban (Eds.), Les politiques de l'enquête. Epreuves ethnographiques. Paris: La Découverte. https://doi.org/10.1111/j.1469-8676.2009.00093_5.x. 
Malinowski, B. (1922). Argonauts of the Western Pacific: An account of native enterprise and adventure in the archipelagoes of Melanesian New Guinea. London: Routledge and Kegan Paul.

Mathieu, N.-C. (Ed.) (1985). L'Arraisonnement des femmes. Essais en anthropologie des sexes [The policing of women. Essays in anthropology of the sexes]. Paris: EHESS.

Médecins Sans Frontières (2010). Violence sexuelle et migration: la réalité cachée des femmes subsahariennes arrêtées au Maroc Sur la route de l'Europe [Sexual violence and migration: The hidden reality of sub-Saharan women arrested in Morocco on the road to Europe]. Retrieved from https://www.msf.fr/sites/default/files/d87b284fadac0af3475 f1f92bce47b3c.pdf.

Médecins Sans Frontières (2013). Violences, vulnérabilités et migration: bloqués aux portes de l'Europe. Un rapport sur les migrants subsahariens en situation irrégulière au Maroc. Violence, vulnerability and migration: blocked at the gates of Europe. A report on sub-Saharan migrants in an irregular situation in Morocco] Rabat: MSF Spain https://www.msf.fr/ sites/default/files/informemarruecos2013_fr_0.pdf.

Merton, R. K. (1948). The self-fulfilling prophecy. The Antioch Review, 8(2), 193-210.

Michel, A. (1985). Le complexe militaro-industriel et la violence à l'égard des femmes [The military-industrial complex and violence against women]. Nouvelles questions Féministes, 11-12, 9-73.

Migreurop (2007). Guerre aux migrants. Le livre noir de Ceuta et Melilla [War on migrants. The black book of Ceuta and Melilla]. Paris: Syllepse.

Migreurop (2009). Atlas des migrants en Europe. Géographie critique des politiques migratoires [Atlas of migrant flow in Europe. Critical geography of migration policies]. Paris: Armand Collin.

Migreurop (2012). Atlas des migrants en Europe. Géographie critique des politiques migratoires. [Atlas of migration in Europe. A critical geography of migration policies] (2nd ed.). Paris: New Internationalist.

Migreurop (2017). Atlas des migrants en Europe. Approche critique des politiques migratoires [Atlas of migrants in Europe. Critical approach to migration policies], (3rd. ed., ). Paris: Armand Collin; London: New Internationalist.

Moffette, D. (2018). Governing irregular migration: Bordering culture, labour and security in Spain. Vancouver: UBC Press.

Morokvasic, M. (2011). L'(in)visibilité continue [Continuing (in)visibility]. Cahiers du Genre, 2011/2(51), 25-47. Retrieved from https://www.cairn.info/revue-cahiers-du-genre-2011-2-page-25.htm.

Pheterson, G. (2001). Le prisme de la prostitution [The prostitution prism] N.- C. Mathieu, trans. Paris: L'Harmattan.

Pian, A. (2008a). Aux portes de Ceuta et Melilla: Regard sociologique Sur les campements informels de bel Younes et de Gourougou [At the gates of Ceuta and Melilla: A sociological look at the informal settlements of bel Younes and Gourougou]. Migrations Société, 116, 11-24. https://doi.org/10.3917/migra.116.0011.

Pian, A. (2008b). Le "tuteur-logeur" revisité [The "landlord-tutor" revisited]. Politique africaine, 109, 91-106. https://doi.org/10. 3917/polaf.109.0091.

Pian, A. (2009). Aux nouvelles frontières de l'Europe: L'aventure incertaine des Sénégalais au Maroc [On Europe's new borders. The uncertain adventure of the Senegalese in Morocco]. Paris: La Dispute.

Pian, A. (2010). La migration empêchée et la survie économique: Services et échanges sexuels des Sénégalaises au Maroc [Blocked migration and economic survival: Sexual services and exchanges of Senegalese women in Morocco]. Cahiers du Genre, 2/2010(49), 183-202.

PorCausa (2017). La industria del control migratorio. ¿Quién gana con las políticas fronterizas de la Unión Europea? [The industry of migration control. The Spanish winners of European Union border policies]. Retrieved from https://porcausa.org/ industriacontrolmigratorio/.

Quijano, A. (2000). Colonialidad del Poder, Eurocentrismo y América Latina [Coloniality of power, eurocentrism, and Latin America]. International Sociology, 15(2), 201-246.

Ramajo, J. (2015). España, denunciada ante la ONU por discriminación racial en la Frontera con Marruecos [Spain, denounced to the UN for racial discrimination on the border with Morocco]. Retrieved from https://www.eldiario.es/andalucia/ discrminacion-racial_0_402110096.html

Saddiki, S. (2010, June 1-3). Ceuta and Melilla fences: A EU multidimensional border. Ottawa: Paper presented at the 82nd. Annual conference of the Canadian Political Science Association Retrieved from https://www.cpsa-acsp.ca/ papers-2010/Saddiki.pdf.

Sanchez, G. (2016). Women's participation in the facilitation of human smuggling: The case of the US southwest. Geopolitics, 21(2), 387-406. https://doi.org/10.1080/14650045.2016.1140645.

Serughetti, G. (2018). Smuggled or trafficked? Refugee or job seeker? Deconstructing rigid classifications by rethinking women's vulnerability. Anti-trafficking review, 11, 16-35 Retrieved from https://www.antitraffickingreview.org/index.php/ atrjournal/article/view/348/284.

Soulé, B. (2007). Observation participante ou participation observante? Usages et justifications de la notion de participation observante en sciences sociales [Participant observation or observant participation? Uses and justifications of the notion of observant participation in the social sciences]. Recherches Qualitatives, 27(1), 127-140.

Stock, I. (2011). Gender and the dynamics of mobility: Reflections on African migrant mothers and 'transit migration' in Morocco. Ethnic and Racial Studies. https://doi.org/10.1080/01419870.2011.594175.

Stock, I. (2018). Ethnography, reflexivity and feminism: Researching sub-Saharan African migrants' perspective on (im)mobility in Morocco. Sage Research Methods Cases. https://doi.org/10.4135/9781526444325.

Tabet, P. (2004). La Grande arnaque. Sexualité des femmes et échange économico-sexuel. [The big scam. Women's sexuality and sexual-economic exchange]. Paris: L'Harmattan.

The Combahee River Collective. (2014). A black feminist statement. Women's Studies Quarterly, 42(3/4), 271-280. Retrieved from http://www.jstor.org/stable/24365010. First appeared in Z. R. Eisenstein (Ed.). (1979). Capitalist patriarchy and the case for socialist feminism. New York: Monthly Review Press.

Timera, M. (2009). Aventuriers ou orphelins de la migration internationale. Nouveaux et anciens migrants « subsahariens » au Maroc [Venturers and forgotten people of international migration. New and old sub-Saharan migrants in Morocco]. Politique africaine, 115, 175-195 https://doi.org/10.3917/polaf.115.0175.

Tyszler, E. (2015). Ceuta et Melilla: Centres de tri à ciel ouvert aux portes de l'Afrique [Ceuta and Melilla: Openair sorting centres at the gateway to Africa]. Retrieved from http://www.migreurop.org/IMG/pdf/fr_rapportconjoint_ceutamelilla_ decembre2015.pdf 
Tyszler, E. (2018a). 'Boza!' Disent aussi les femmes ['Boza!' Also say women]. Vacarme, 83(2), 82-91. https://doi.org/10.3917/ vaca.083.0082.

Tyszler, E. (2018b). Sécurisation des frontières et violences contre les femmes en quête de mobilité [Securitization of borders and violence against women in search of mobility]. Migrations Société, 173, 143-158. https://doi.org/10.3917/migra.173.0143.

Üstübici, A. (2015). Dynamics in emigration and immigration policies of Morocco: A double engagement. Migration and Development, 4(2), 238-255. https://doi.org/10.1080/21632324.2015.1022083.

Women's Link Worldwide (2009). Los derechos de las mujeres migrantes, una realidad invisible [the rights of migrant women, an invisible reality]. Retrieved from https://womenslinkworldwide.org/files/1350/los-derechos-de-las-mujeres-migrantes.pdf.

Submit your manuscript to a SpringerOpen ${ }^{\circ}$ journal and benefit from:

- Convenient online submission

- Rigorous peer review

- Open access: articles freely available online

High visibility within the field

- Retaining the copyright to your article

Submit your next manuscript at $\boldsymbol{\nabla}$ springeropen.com 